\title{
PENTINGNYA KEPUASAN PELANGGAN BAGI TRAVEL HAJI DAN UMROH DI BANJARMASIN
}

\author{
Devi Noviyanti \\ UIN Antasari Banjarmasin
}

\begin{abstract}
The customer's satisfaction should be the priority of hajj and umroh travel agency in high competition, especially in Banjarmasin. The customer's satisfaction is a ratio between prospects and performance. It is very meaningful to the company. The company can measure the satisfaction rate using many strategies for the on going improvement of company management.
\end{abstract}

Keywords: customer's satisfaction, prospects, performance, meaningful, strategy

\section{Pendahuluan}

Kepuasan pelanggan merupakan suatu konsep yang telah lama dikenal dalam teori dan aplikasi pemasaran. Kepuasan pelanggan menjadi salah satu tujuan esensial bagi aktivitas bisnis, dipandang sebagai salah satu indikator terbaik untuk meraih laba di masa yang akan datang serta menjadi pemicu upaya untuk meningkatkan kepuasan konsumen. Setiap waktu, persaingan bisnis semakin meningkat tajam, preferensi dan perilaku pelanggan berubah, teknologi informasi berkembang dengan cepat sehingga mendorong organisasi bisnis untuk lebih focus menanggapi kepuasan pelanggan untuk menjamin pengembangan dan keberlanjutan bisnis.

Produsen atau penyedia jasa harus selalu berusaha memenuhi kebutuhan dan keinginan konsumen disaat persaingan semakin ketat dengan menawarkan berbagai jenis produknya. Namun dengan adanya berbagai tawaran ini, dapat memberikan dampak berupa konsumen memiliki banyak pilihan dan kekuatan tawar-menawar konsumen semakin besar sehingga perusahaan harus senantiasa berorientasi pada kepuasan pelanggan sebagai tujuan utamanya. Oleh karena itu, perusahaan harus memiliki strategi untuk dapat memenangkan persaingannya.

Bisnis penyedia jasa perjalanan (travel) haji dan umroh di Banjarmasin saat ini merupakan bisnis yang banyak diminati. Haji dan umroh merupakan salah satu bentuk wisata ziarah dalam Islam. Haji dan umroh dikatakan sebagai wisata ziarah, karena kedua kegiatan ini merupakan suatu bentuk kegiatan perjalanan yang dilakukan seseorang atau sekelompok orang dengan mengunjungi tempat tertentu yang bertujuan untuk kegiatan ibadah ataupun rekreasi, pengembangan pribadi serta mempelajari keunikan daya tarik wisata yang dikunjungi dalam waktu sementara. Hal tersebut sesuai dengan pengertian wisata dalam pasal 1 Undang-undang No. 10 tahun 2009 tentang kepariwisataan (Sulastri dalam Dewi, 2013).

Haji merupakan rukun islam yang kelima setelah syahadat, shalat, puasa dan zakat. Dalam pelaksanaanya, hukum haji diwajibkan, lain halnya dengan umroh (haji kecil). Umroh merupakan kunjungan ke Ka'bah dimana di dalamnya wisatawan (jamaah) melakukan serangkaian ibadah dengan syarat-syarat yang telah ditetapkan. Umroh disunatkan bagi muslim yang mampu, baik kemampuan secara fisik maupun secara finansial serta keilmuan dan dapat dilaksanakan kapan saja, kecuali pada hari Arafah yaitu tanggal 10 Dzulhijah dan hari-hari Tasyrik yaitu tanggal 11, 12, 13 
Dzulhijah. Hal ini berbeda dengan ibadah haji yanghanya dapat dilaksanakan pada waktu-waktu tertentu dan diwajibkan dalam pelaksanaanya bagi yang berkemampuan.

Menurut pengamatan penulis, banyaknya bermunculan bisnis travel haji dan umroh di Banjarmasin ini karena banyaknya masyarakat yang ingin melaksanakan ibadah haji dan umroh ini. Hal ini didukung pula oleh semakin panjangnya waktu tunggu bagi calon jamaah untuk dapat melaksanakan ibadah haji. Dengan demikian kehadiran penyelenggara haji dan umrah ini dapat membantu untuk memfasilitasi masyarakat yang berminat untuk segera mewujudkan keinginan mereka melaksanakan ibadah haji dan umroh.

Berikut daftar penyelenggara (travel) haji dan umrah di Kalimantan Selatan yang sudah memiliki izin resmi untuk mengelola perjalanan ibadah haji dan umrah yang didapatkan dari Bidang Penyelenggaraan Haji dan Umrah (PHU) Kantor Wilayah Kementerian Agama Provinsi Kalsel : 
DAFTAR PENYELENGGARA PERJALANAN IBADAH UMROH DAN PENYELENGGARA IBADAH HAII KHUSUS

PROVINSI KALIMANTAN SELATAN

TAHUN 1436 H/ 2015

\begin{tabular}{|c|c|c|c|c|c|c|c|}
\hline \multirow{3}{*}{ NO } & \multirow{3}{*}{ PENYELENGGARA } & \multicolumn{3}{|c|}{ PENYELENGGARA IBADAH HAJI UMRAH } & \multirow{3}{*}{ PIMPINAN } & \multirow{3}{*}{ ALAMAT } & \multirow{3}{*}{ KET } \\
\hline & & \multirow{2}{*}{ NO.SK } & \multicolumn{2}{|c|}{ SKBERLAKU } & & & \\
\hline & & & MULAI & BERAKHIR & & & \\
\hline 1 & PT. IDAH ROES & D/292 TH 2013 & 26107/2013 & 2610712016 & NANA SUHARTINI & JI. Sultan adam Banjarmasin & PIKK \\
\hline 2 & PT.RIYAL TUNGGAL & D1509 TH 2013 & 26107/2013 & $26 / 07 / 2016$ & HJ,MARLIANA & $\begin{array}{l}\text { JL.Jend.A.Yani No } 407 \text { B.JM. Telp. 0511.3250915 Fax. } \\
0511.3250916\end{array}$ & PIHK \\
\hline 3 & PT. KALTRABU INDAH & D/545 TH 2014 & 19/08/2013 & 19/08/2016 & DRA, HJ.MARWIYYHF, ZUHRI & $\begin{array}{l}\text { Jt. Jend A. Yani Ruko Seberang Polresta Banjarmasin Telp. 0511. } \\
\text { 3262501, 3352168, fax 0511.3351768 HP.085390372314 }\end{array}$ & PIHK \\
\hline 4 & PT. PANCAR NI'MAH & D/332 TH 2014 & 27/1212014 & 2711222017 & HJ. NURJANAH & $\begin{array}{l}\text { JL.Sekumpul No. } 66 \text { IITP,BJM. Telp. 0511.4720929 Fax. } 0511.4720709 \\
\text { HP.085249332060 }\end{array}$ & PIHK \\
\hline 5 & PT. SALFANY SAFANUSA & D/354 TH 2013 & $11 / 0612013$ & $1106 / 2016$ & H. ABU HANIFAH & $\begin{array}{l}\text { JL.Cempaka Besar No. } 41 \text { BJM. Telp. 0511.365674, 66495 Fax, } \\
\text { 0511.361993 HP.082153635566 }\end{array}$ & PHK \\
\hline 6 & PT. SAIDI PUTRA WISATA & D/170 TH 2012 & 23/04/2012 & 231042015 & MUHAMMAD ISMALL, SE & $\begin{array}{l}\text { JL. Pangeran Antasari NO. } 96 \text { A B.JM, Telp, 0511.3258701, } \\
3260589,3250174 \text { Fax. 0511.3263441 HP.081349915599 }\end{array}$ & PIHK \\
\hline 7 & PT. ABSAS AL.RAHALAH TOUR & D/316 TH 2013 & 26:07/2013 & $26107 / 2016$ & H. ABU BAKAR SIDOIQ & Jl Pahlawan VIII10 RT007/03 Bjm,(0511) 3274562 & PPIU \\
\hline 8 & PT. SURYA DHARMA WISATA & D.635 TH 2012 & $10 / 0812012$ & $10108 / 2015$ & EDY SUPRIADI & $\begin{array}{l}\text { JL. Pangeran Antasari No. } 96 \text { A B.JM. Telp, } 0511.3250174,3258701 \\
\text { Fax. } 0511.3263441\end{array}$ & PIHK \\
\hline 9 & $\begin{array}{l}\text { PT. TRAVELLINDO LUSIYANA } \\
\text { (Pervakilan) }\end{array}$ & D/551 TH 2011 & $07 / 110 / 2010$ & 0711012013 & H. SUPRIADL, SPd. MM & $\begin{array}{l}\text { Komp. Ruko } 53 \text { J. Pangeran Hidayatullah, BJM. Telp. } \\
0511.431549,6292729 \mathrm{Fax} .0511 .4315482\end{array}$ & PIHK \\
\hline 10 & PT. MAKMUUR MULLA & D/57 TH 2013 & $06: 0222013$ & 0610222016 & H. MUHTASAR & $\begin{array}{l}\text { J1. Teluk Tiram Darat 10 (Melati No. } 01 \text { Rt. } 19 \text { Kelurahan Telawang } \\
\text { Banjarmasin telp. } 0511.7529318 \text { tax. } 4240239\end{array}$ & PPIU \\
\hline 11 & PT. ALBIS NUSA WISATA & D/619 TH 2014 & 20/11/2014 & 20/1112017 & M. RIO RUBYANOR & JI. Banjar Indah IV No. 14 Eanjarmasin 4781355/4782377 Fax 4780348 & PPIU \\
\hline 12 & PT.AL. BANJARY & D/829 TH 2012 & 28/12/2012 & 281122015 & ORS. H. NAJMII AL ALI & J1. Manggis No. 47 Banjarmasin Telp. 05117400550 tax. 3269223 & PPIU \\
\hline 13 & PT. NAMIRA AMALIA UTAMA & D/ 569 TH 2013 & 271122013 & 2711212016 & H. M. RUSLI KASIM & $\begin{array}{l}\text { Ji. Sekumpul No. } 16 \text { Martapura Telp. '0511 4720929, 4721819, tax } \\
\text { 4721815 }\end{array}$ & PIHK \\
\hline 14 & PT. QALEU AMANAH PERDANA & D/85 TH 2012 & 26103/2012 & 2610312015 & H. GUSTIFAISAL, SE & 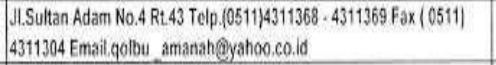 & PPIU \\
\hline 15 & PT. BANU MIERAS WISATA & D/109 TH 2013 & $27 / 1222013$ & 27/12:2016 & H. SUPRIADI, SPd MM & $\begin{array}{l}\text { Komp. Ruko } 53 \text { JI. Pangeran Hidayatullan,BJML. Tolp: } \\
\text { 0511 431549,6292729 Fax, 0511.4315482, }\end{array}$ & PPU \\
\hline 16 & PT. BAGUS UMRA TAMA & DH169 TH 2013 & 24105/2012 & $2405 / 2015$ & HJZALNA & $\begin{array}{l}\text { Jl Pramuka No 45 RT } 12 \text { Kel Pangambangan } \\
\text { Eanjarmasin.08125042667/ } 3251265\end{array}$ & PPIU \\
\hline 17 & PT. RANDI PRIMA WISATA & Di289 TH 2013 & 240512013 & $2405 / 2016$ & M. RIZAL PALUPPI & Jl. Pulau Laut No 16 Ri D3/01 Kol Antasan Besar B.JA Tlp.05113364052 & PPIU \\
\hline 18 & $\begin{array}{l}\text { PT. TAIBAH SEMESTA WISATA } \\
\text { (Perwakilan) }\end{array}$ & Di397 Tahun 2012 & $24 / 05 / 2012$ & 2405/2015 & H. UJANG & JI Sultan Adam (Ruko) No 7 RT 19 Banjamasin & PPIU \\
\hline 19 & $\begin{array}{l}\text { PT. AI TAIF SAUDI WISATA } \\
\text { (perwakilan) }\end{array}$ & D/326 Tahun 2013 & $03 / 06 / 2013$ & $0306 / 2016$ & IUUHAMMAD FAISAL & JIA. Yani Km 39,5 Martapura.0511-4722414 & PPIU \\
\hline 20 & PT. MADINA WUSATA ABADI & Di418 Tahun 2013 & 0110712013 & $0107 / 2015$ & ABADINOR MADLAN KARIII & $\begin{array}{l}\text { Ji Brigjen H. Hasan Basn Rt.002101 Amuntai Kab HSU. 0527. } \\
636800081251444449\end{array}$ & PPIU \\
\hline 21 & PT. WAHDAN SABILANA & Di4456 Tahun 2013 & $29107 / 2813$ & 29:07/2016 & H.FAISAL & $\begin{array}{l}\text { JL. Jend A. Yani Ruko Seberang Polresta Barijarmasin Telp. } 0511 \text {. } \\
3362325,3352168, \text { fax 0511-3351768 }\end{array}$ & PPIU \\
\hline
\end{tabular}




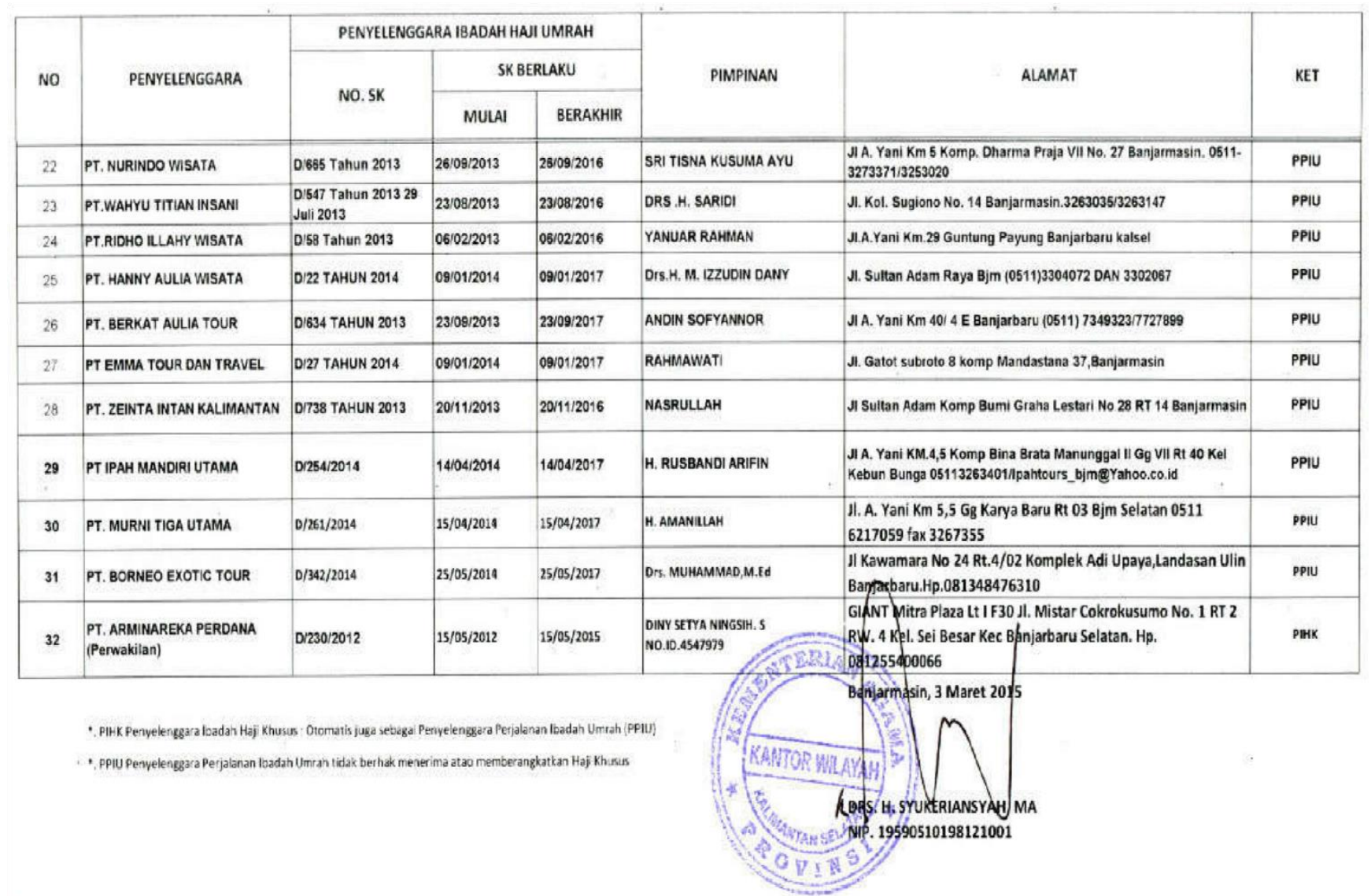

Gambar 1 Daftar Penyelenggaran Perjalanan Ibadah Umroh dan Penyelenggaraan Ibadah Haji Khusus Provinsi Kalimantan Selatan Tahun 2015

Sumber: www.kalsel.kemenag.go.id

Mengingat banyaknya perusahaan yang menyediakan jasa penyelenggaraan ibadah haji di Kalimantan Selatan yakni 32 buah dan sebagian besarnya di Banjarmasin yakni 25 buah pada tahun 2015 (dapat dilihat pada di atas), maka perusahaan harus senantiasa dapat melakukan persaingan dan memenangkannya. Dalam hal ini, perusahaan harus selalu berusaha melakukan strategi pemasaran yang tepat dan memberikan pelayanan yang terbaik kepada konsumennya agar konsumen mereka tersebut dapat terpuaskan. Hal yang harus diyakini oleh perusahaan adalah bahwa kunci sukses untuk memenangkan persaingan terletak pada kemampuannya memberikan total customer value yang dapat memuaskan pelanggan melalui penyampaian produk yang berkualitas dengan harga bersaing. Selain itu, dengan adanya kepuasan akan mengarahkan orang untuk mengulangi pembelian dan melakukan rekomendasi word of mouth yang positif terhadap perusahaan. Oleh karena itu, sangat penting kiranya bagi perusahaan travel haji dan umrah di Banjarmasin untuk senantiasa memperhatikan kepuasan pelanggannya.

\section{Pembahasan \\ Definisi Pemasaran}

Menurut Kotler (2005:10), pemasaran adalah proses sosial yang dengan proses itu individu dan kelompok mendapatkan apa yang mereka butuhkan dan inginkan 
dengan menciptakan, menawarkan dan secara bebas mempertukarkan produk dan jasa yang bernilai dengan pihak lain. Berdasarkan definisi tersebut dapat disimpulkan bahwa proses pemasaran bertujuan untuk memuaskan konsumennya.

\section{Nilai dan Kepuasan Pelanggan}

Kotler (2005:68) menyebutkan bahwa nilai yang dipikirkan pelanggan adalah selisish antara evaluasi calon pelanggan atas semua manfaat serta semua biaya tawaran tertentu dan alternatif-alternatif yang dipikirkan. Sedangkan nilai pelanggan total (total customer value) adalah nilai moneter yang dipikirkan atas sekumpulan manfaat ekonomis, fungsional, dan psikologis yang diharapkan oleh pelanggan atas tawaran pasar tertentu. Biaya pelanggan total (total customer cost) adalah sekumpulan biaya yang pelanggan harapkan untuk dikeluarkan guna mengevaluasi, mendapatkan, menggunakan dan membuang tawaran pasar tertentu.

Konsep kepuasan pelanggan dapat digambarkan menurut beberapa pendapat para ahli dalam Hasan (2013:90) berikut ini :

a. Kepuasan atau ketidakpuasan merupakan respon pelanggan terhadap evaluasi ketidaksesuaian yang dipersepsikan antara harapan sebelum pembelian dan kinerja aktual produk yang dirasakan setelah pemakaiannya.

b. Kepuasan atau ketidakpuasan merupakan evaluasi purnabeli dimana alternatif yang dipilih sekurang-kurangnya sama atau melampaui harapan pelanggan, sedangkan ketidakpuasan timbul apabila hasil tidak memenuhi harapan.

c. Kepuasan atau ketidakpuasan sebagai evaluasi purnabeli, dimana persepsi terhadap kinerja produk yang dipilih memenuhi atau melebihi harapan sebelum pembelian. Apabila persepsi terhadap kinerja tidak dapat memenuhi harapan, maka yang terjadi adalah ketidakpuasan. Ketidaksesuaian menciptakan ketidakpuasan.

d. Kepuasan atau ketidakpuasan merupakan suatu perasaan konsumen sebagai respon terhadap produk barang atau jasa yang telah dikonsumsi.

e. Kepuasan atau ketidakpuasan merupakan perbandingan antara produk yang dirasakan dengan yang diprediksi sebelum produk dibeli-dikonsumsi. Jika yang dirasakan konsumen melebihi dugaannya, konsumen akan merasakan puas, sebaliknya jika yang dirasakan lebih rendah dari harapannya, konsumen akan merasa tidak puas.

Kepuasan pelanggan berdasarkan lima perspektif sebagai berikut :

Tabel 1 Lima Perspektif Kepuasan Pelanggan

\begin{tabular}{|l|l|}
\hline \multicolumn{1}{|c|}{ PERSPEKTIF } & DEFINISI KEPUASAN PELANGGAN \\
\hline Normative deficit & $\begin{array}{l}\text { Perbandingan antara hasil aktual dengan } \\
\text { hasil yang secara cultural dapat diterima. }\end{array}$ \\
\hline Equity & $\begin{array}{l}\text { Perbandingan perolehan/keuntungan yang } \\
\text { didapatkan dari pertukaran sosial, bila } \\
\text { perolehan tersebut tidak sama, maka } \\
\text { pihak yang dirugikan tidak puas. }\end{array}$ \\
\hline
\end{tabular}




\begin{tabular}{|l|l|}
\hline Normative standar & $\begin{array}{l}\text { Perbandingan antara hasil aktual dengan } \\
\text { harapan standar pelanggan (yang dibentuk } \\
\text { dari pengalaman dan keyakinan mengenai } \\
\text { tingkat kinerja yang seharusnya ia terima } \\
\text { dari merek tertentu). }\end{array}$ \\
\hline Procedural fairness & $\begin{array}{l}\text { Kepuasan merupakan fungsi dari } \\
\text { keyakinan/persepsi konsumen bahwa ia } \\
\text { telah diperlakukan secara adil. }\end{array}$ \\
\hline Atrtibutional & $\begin{array}{l}\text { Kepuasan tidak hanya ditentukan oleh ada } \\
\text { tidaknya diskonfirmasi harapan, namun } \\
\text { juga penyebab } \\
\text { diskonfirmasi. }\end{array}$ \\
\hline
\end{tabular}

Dengan demikian, dapat dipahami bahwa definisi mengenai kepuasan pelanggan tidak ada yang baku, karena kepuasan pelanggan tergantung pada :

1. Tipe respon : respon kognitif, afektif dan emosional terhadap produk yang digunakan, khususnya ketika mereka membandingkan kinerja yang ia rasakan dengan harapannya, dan intensitas respon seperti sangat kuat, sangat puas, netral, sangat senang dan sejenisnya.

2. Fokus respon : terutama yang berkaitan jenis produk, konsumsi, keputusan pembelian, staf penjualan, dan sejenisnya.

3. Timing respon : respon yang muncul setelah mengkonsumsi, setelah pembelian, akumulasi pengalaman dan sejenisnya.

Kepuasan pelanggan merupakan fungsi dasar dari sejumlah value produk yang dipersepsikan oleh pelanggan dibanding dengan harapan pelanggan sebelum menggunakan. Rumusan ini diformulasikan sebagai berikut :

Kepuasan $=\mathrm{f}$ (harapan terhadap produk : Kinerja produk yang dirasakan)

Dari persamaan itu, kemungkinan pelanggan akan menyatakan kepuasan dalam berbagai bentuk perilaku sebagai berikut (Hasan, 2013:91) :

Tabel 2 Kepuasan dalam Berbagai Bentuk Perilaku

\begin{tabular}{|l|l|l|l|l|}
\hline \multicolumn{2}{|r|}{ Apabila } & Pelanggan & \multicolumn{1}{|c|}{ Dampak } \\
\hline a. & $\begin{array}{l}\text { Kinerja }> \\
\text { harapan }\end{array}$ & $\longrightarrow$ & Sangat puas & $\begin{array}{l}\text { Kunjungan } \\
\text { ulang, } \\
\text { rekomendasi } \\
\text { positif }\end{array}$ \\
\hline b. & $\begin{array}{l}\text { Kinerja }= \\
\text { harapan }\end{array}$ & $\longrightarrow$ & Puas & Silence \\
\hline c. & $\begin{array}{l}\text { Kinerja } \\
\text { harapan }\end{array}$ & $\longrightarrow$ & Kecewa & $\begin{array}{l}\text { Rekomendasi } \\
\text { negative }\end{array}$ \\
\hline
\end{tabular}


Sebagai gambaran mengenai kepuasan dan ketidakpuasan pelanggan dapat diperlihatkan oleh gambar berikut :

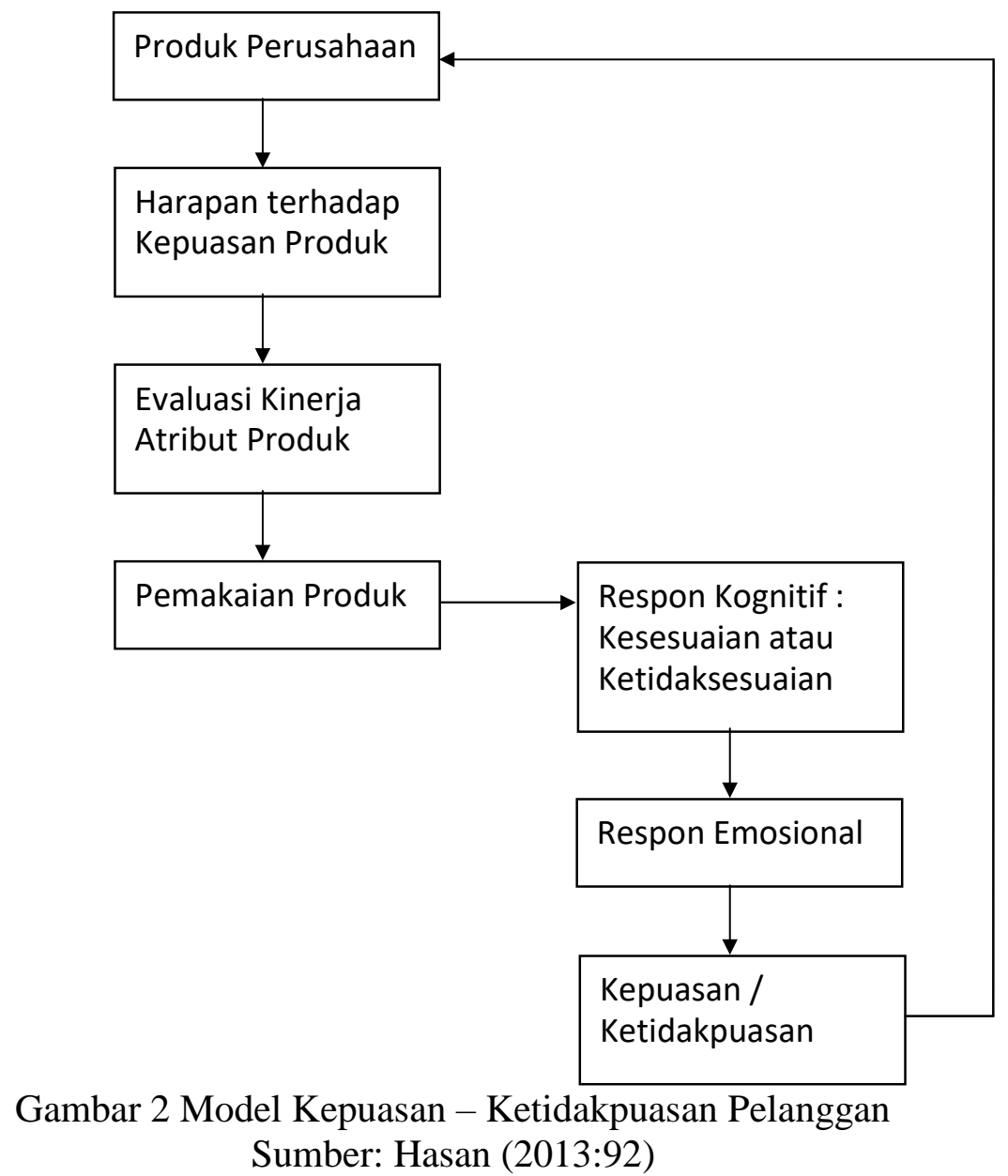

\section{Konsep Kepuasan Pelanggan}

Formulasi untuk meningkatkan kepuasan pelanggan dan loyalitas (increased customer satisfaction and loyalty) dapat dilakukan dengan cara melakukan pekerjaan pertama kali dengan benar (doing the right job on the first time), kemudian menangani complain dengan efektif (effective complaint handling).

Doing the right job on the first time

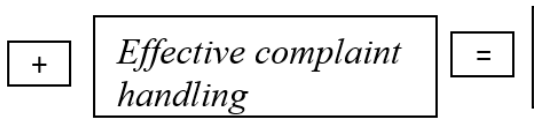

Increased customer satisfaction \& loyalty

Gambar3 Konsep Kepuasan Pelanggan

Sumber: Hasan (2013:93) 


\section{Arti Penting Kepuasan Pelanggan Bagi Perusahaan Travel Haji dan Umrah}

Bisnis penyelenggara (travel) ibadah haji dan umroh semakin hari semakin banyak, termasuk di Banjarmasin. Oleh karena itu, persaingan bisnis di bidang penyelenggara ibadah haji dan umrohpun semakin terasa. Salah satu faktor yang mendorong adalah banyaknya peminat (masyarakat) yang memiliki keinginan untuk berangkat ke Tanah Suci untuk melaksanakan ibadah baik haji maupun umrah, sementara waktu tunggu untuk melaksanakan ibadah haji secara regular semakin panjang. Keinginan masyarakat untuk melaksanakan ibadah ini dengan segera dapat difasilitasi oleh hadirnya travel haji dan umroh.

Produk yang diberikan oleh travel haji dan umroh kepada pelanggannya berupa produk jasa. Kotler (2005:11) mendefinisikan "jasa adalah setiap tindakan atau kinerja yang dapat ditawarkan satu pihak kepada pihak lain, yang pada dasarnya tidak berwujud dan tidak mengakibatkan kepemilikan sesuatu”. Sedangkan Lamb, Hair dan Mc.Daniel (2001:482) menyebutkan bahwa "jasa adalah hasil dari usaha penggunaan manusia dan mesin terhadap sejumlah orang atau objek". Jasa meliputi perbuatan, suatu kinerja, atau suatu upaya yang tidak bisa diproses secara fisik.

Berdasarkan definisi jasa di atas, dapat diketahui bahwa jasa itu sendiri bersifat abstrak. Oleh karena itu, travel haji dan umroh yang sesungguhnya mengeluarkan produk jasa tersebut harus selalu memperhatikan kepuasan pelanggannya. Terlebih lagi perusahaan travel haji dan umroh saat ini mengalami persaingan yang sangat tinggi seperti di Banjarmasin. Salah satu cara untuk memberikan kepuasan kepada pelanggan adalah dengan memperhatikan kualitas jasa itu sendiri.

Kualitas jasa berpusat pada upaya pemenuhan kebutuhan dan keinginan pelanggan serta ketepatan penyampaiannya untuk mengimbangi harapan pelanggan. Menurut Wyckof dalam Tjiptono (2004:59), "kualitas jasa adalah tingkat keunggulan yang diharapkan dan pengendalian atas tingkat keunggulan tersebut untuk memenuhi keinginan pelanggan”. Menurut Parasuraman dalam Kotler (2005:123), kualitas jasa meliputi keandalan (reliability), daya tanggap (responsiveness), jaminan (assurance), empati (empathy), dan bukti langsung (tangible).

Dimensi kualitas jasa seperti yang disebutkan di atas dapat digunakan oleh travel haji dan umroh di Banjarmasin untuk memberikan kepuasan kepada pelanggannya, antara lain sebagai berikut :

a. Keandalan (reliability)

Keandalan merupakan kemampuan melaksanakan layanan yang dijanjikan secara meyakinkan dan akurat. Berkaitan dengan keandalan ini, maka perusahaan travel haji dan umroh dituntut untuk dapat memberikan pelayanan sesuai dengan janji yang diberikan kepada pelanggan dan melaksanakannya sesuai dengan prosedur. Misalnya memberangkatkan jemaah sesuai dengan jadwal, harga sesuai dengan yang disampaikan tanpa ada biaya tambahan di luar kesepakatan serta memberikan fasilitas transportasi dan penginapan (hotel) sesuai dengan janji.

b. Daya tanggap (responsiveness)

Daya tanggap merupakan kesediaan membantu pelanggan dan memberikan jasa dengan cepat. Dalam hal ini, kecepatan pelayanan menjadi salah satu hal yang harus diperhatikan oleh perusahaan travel haji dan umroh. Misalnya, segala kebutuhan atau keperluan jemaah yang memerlukan pelayanan dari pihak travel dilaksanakan secara cepat tanpa adanya waktu tunggu yang lama bagi jemaah. Hal ini dilakukan guna menghindari keluhan dari jemaah sebagai pelanggannya.

c. Jaminan (assurance) 
Jaminan berhubungan dengan kemampuan perusahaan dan perilaku frontline staf dalam menanamkan rasa percaya dan keyakinan kepada para pelanggannya. Berdasarkan banyak riset yang dilakukan, ada 4 (empat) aspek dari dimensi ini, yaitu keramahan, kompetensi, kredibilitas dan keamanan. Berkaitan dengan jaminan ini, banyak hal yang bisa dilakukan oleh travel haji dan umroh untuk memberikan kepuasan kepada pelanggannya. Hal tersebut antara lain tingginya kemampuan karyawan travel terutama front-line staf dalam menjawab berbagai pertanyaan yang diajukan pelanggan berkaitan dengan produk ataupun perusahaan;

d. Empati (empathy)

Empati merupakan perhatian secara individual yang diberikan oleh perusahaan kepada konsumen. Misalnya kemudahan untuk menghubungi perusahaan, kemampuan karyawan untuk berkomunikasi dengan pelanggan dan usaha perusahaan untuk memahami kebutuhan dan keinginan pelanggannya. Perusahaan travel haji dan umroh dapat memanfaatkan dimensi ini untuk memberikan dan meningkatkan kepuasan pelanggannya. Misalnya karyawan yang dengan penuh perhatian mendengarkan berbagai keluhan dan saran dari pelanggan, petugas yang dengan setia dan sabar mendampingi pelanggan dalam melaksanakan ibadah, ataupun pihak perusahaan yang selalu berkomunikasi dengan pelanggan demi memenuhi segala kebutuhan dan keinginan pelanggan.

e. Bukti Langsung (tangible)

Tangible adalah bukti konkret kemampuan suatu perusahaan untuk menampilkan yang terbaik bagi pelanggan. Hal ini dapat dibuktikan baik dari sisi fisik tampilan bangunan, fasilitas, perlengkapan teknologi pendukung, hingga penampilan karyawan. Perusahaan travel haji dan umroh dapat menggunakan dimensi ini untuk mendapatkan kepuasan pelanggan dan meningkatkannya, antara lain dengan memberikan fasilitas yang sesuai dan terbaik bagi pelanggan mulai dari alat trasnsportasi, penginapan dan makanan bagi pelanggan. Hal lain yang dapat diberikan perusahaan dengan memberikan perlengkapan yang sangat diperlukan di Tanah Suci seperti tas dan peralatan shalat seperti mukena. Tentunya fasilitas ini sangat membantu pelanggan yang dalam hal ini para jamaah demi kelancaran menjalankan ibadah.

Tingginya minat masyarakat untuk melaksanakan ibadah haji dan umroh ini dan selanjutnya kemudian memutuskan untuk menggunakan fasilitas yang disediakan oleh travel harus disambut baik oleh pihak travel. Hal ini dapat dilakukan dengan memberikan kepuasan kepada pelanggannya dengan berbagai cara dan strategi, antara lain dengan memberikan produk (jasa) yang berkualitas sesuai dengan janji yang diberikan, harga yang dapat dijangkau, fasilitas yang lengkap, memberikan pelayanan prima yang penuh dengan kesopanan, ramah dan santun serta memberikan penyelesaian atas masalah pelanggan dengan tanggap dan cepat. Apabila hal ini dilakukan secara berkelanjutan, maka diharapkan kepuasan pelanggan akan didapatkan.

Kepuasan pelanggan itu sendiri memberikan banyak arti penting bagi perusahaan, termasuk travel haji dan umrah. Menurut Harkiranpal dalam Hasan (2013:102-104), lebih dari 20.000 temuan survey kepuasan pelanggan yang dilakukan di 40 negara, yang merekomendasikan bahwa perencanaan, implementasi, pengendalian program kepuasan pelanggan yang bagus dapat memberikan manfaat bagi perusahaan, diantaranya sebagai berikut :

1. Pendapatan 
a. Pelanggan yang benar-benar puas berkontribusi 2,6 kali terhadap pendapatan dibanding pelanggan yang agak puas.

b. Pelanggan yang benar-benar puas berkontribusi 17 kali terhadap pendapatan dibanding pelanggan yang agak puas.

c. Penurunan kepuasan pelanggan mengakibatkan penurunan pendapatan 1,8 kali.

d. Pelanggan yang puas yang paling mungkin berbagi pengalaman dengan orang lain lima sampai enam orang. Sebaliknya, pelanggan yang tidak puas akan mengatakan pengalaman yang mengecewakan kepada sepuluh orang.

e. Jika orang percaya bahwa berurusan dengan kepuasan pelanggan atau keluhan itu mahal, mereka perlu menyadari bahwa biaya untuk merekrut pelanggan baru lebih besar dari biaya mempertahankan pelanggan lama.

f. Pelanggan yang tidak puas memutuskan untuk :

$\checkmark$ Menghentikan membeli produk (barang dan jasa)

$\checkmark$ Mengeluh kepada perusahaan atau kepada pihak ketiga

$\checkmark$ Mengembangkan komunikasi negatif dari mulut ke mulut (negative word of mouth communication)

2. Reaksi terhadap produsen berbiaya rendah

Persaingan dengan "perang harga" ataupun pemotongan harga dianggap oleh banyak perusahaan menjadi senjata ampuh untuk meraih pangsa pasar (sekalipun sebenarnya sangat rapuh). Cukup banyak fakta bahwa pelanggan yang bersedia membayar harga yang lebih mahal untuk pelayanan dan kualitas produk yang lebih baik. Strategi focus pada kepuasan pelanggan merupakan alternatifterbaik dalam mempertahankan pelanggan untuk menghadapi para produsen berbiaya rendah.

3. Manfaat ekonomis

Berbagai studi menunjukkan bahwa mempertahankan dan memuaskan pelanggan saat ini jauh lebih mudah disbandingkan terus-menerus berupaya menarik atau memprospek pelanggan baru. Biaya mempertahankan pelanggan yang sudah ada lebih murah empat sampai enam kali lipat dibandingkan biaya mencari pelanggan baru.

4. Reduksi sensivitas harga

Pelanggan yang puas terhadap sebuah perusahaan cenderung lebih jarang menawar harga untuk setiap pembelian individualnya. Dalam banyak kasus, kepuasan pelanggan mengalihkan focus pada harga pelayanan dan kualitas.

5. Kunci sukses bisnis masa depan

a. Kepuasan pelanggan merupakan strategi bisnis jangka panjang, membangun dan memperoleh reputasi produk bagi perusahaan dibutuhkan waktu yang cukup lama, diperlukan investasi besar pada serangkaian aktivitas bisnis untuk membahagiakan pelanggan.

b. Kepuasan pelanggan merupakan indicator kesuksesan bisnis di masa depan yang mengukur kecenderungan reaksi pelanggan terhadap perusahaan di masa yang akan datang.

c. Program kepuasan pelanggan relative mahal, namun mendatangkan laba jangka panjang yang bertahan lama.

d. Ukuran kepuasan pelanggan lebih prediktif untuk kinerja masa depan.

6. Word of mouth relationship, pelanggan yang puas dapat :

a. Menjadikan hubungan antara perusahaan dan pelanggannya menjadi harmonis. 
b. Memberikan dasar yang baik bagi pembelian ulang dan terciptanya loyalitas pelanggan.

c. Menjadi advocator bagi perusahaan, terutama ketika reputasi perusahaan/produk dilecehkan orang lain.

d. Membentuk rekomendasi positif dari mulut ke mulut yang sangan menguntungkan bagi perusahaan.

Melihat arti penting dari kepuasan pelanggan itu sendiri bagi perusahaan, maka sudah seharusnya pihak travel haji dan umroh memberikan dan mengukur kepuasan semua pelanggannya. Perusahaan travel dapat melaksanakan berbagai strategi untuk mengukur tingkat kepuasan pelanggannya. Hal ini penting agar apabila ada ketidakpuasan yang dirasakan oleh pelanggan dapat diatasi dengan segera sehingga tidak berkelanjutan. Langkah ini juga penting dilaksanakan sebagai bahan masukan untuk pengembangan travel menjadi lebih baik.

Pengukuran kepuasan pelanggan ini hendaknya dilakukan oleh perusahaan travel secara rutin dan terus menerus agar dapat menilai setiap perubahan yang terjadi dalam kaitannya dengan jalinan relasi dengan setiap pelanggan. Perlu pula disadari bahwa kunci untuk mempertahankan pelanggan adalah kepuasan pelanggan itu sendiri. Pelanggan yang sangat puas akan tetap setia dalam waktu yang lebih lama, membeli lebih banyak ketika perusahaan memperkenalkan produk baru dan memperbaharui produk-produk yang ada dan membicarakan hal-hal yang baik tentang perusahaan dan produknya.

Menurut Kotler (2005:72), kepuasan pelanggan dapat dilacak dan diukur dengan beberapa cara, yaitu system keluhan dan saran, survey kepuasan pelanggan, belanja siluman (ghost shopping) dan analisis pelanggan yang hilang (lost customer analysis). Travel haji dan umroh khususnya di Banjarmasin dapat melaksanakan strategi tersebut untuk mengukur kepuasan pelanggan pelanggan mereka. Sebagai gambaran aplikasi strategi tersebut bagi travel haji dan umrah di Banjarmasin antara lain sebagai berikut :

1. Sistem keluhan dan saran

Sistem ini dapat dilakukan oleh perusahaan travel untuk memberikan kesempatan kepada pelanggan untuk menyampaikan saran secara langsung, misalnya dengan menggunakan kotak saran. Informasi-informasi yang yang diperoleh melalui metode ini dapat memberikan ide-ide baru dan masukan yang berharga untuk direspon dengan cepat untuk mengatasi keluhan pelanggan.

2. Belanja siluman (Ghost shopping)

Metode ini dilakukan untuk mengetahui secara langsung bagaimana karyawan perusahaan travel itu sendiri atau karyawan perusahaan travel lain berinteraksi dan memperlakukan pelanggan. Hal ini bisa dilakukan oleh perusahaan travel dengan meminta orang lain untuk berperan sebagai calon pelanggan guna melaporkan titik kuat dan titik lemah yang dialami sewaktu membeli produk dari perusahaan travel atau perusahaan travel pesaing. Pembelanja misterius itu bahkan dapat menguji cara karyawan perusahaan travel menangani berbagai situasi. Metode ini dapat dilakukan pula oleh manajer atau pimpinan travel langsung yang berpurapura sebagai calon pelanggan. Misalnya dengan cara menelpon perusahaannya sendiri dan melontarkan berbagai keluhan ataupun pertanyaan kepada karyawan yang tidak tahu bahwa dia sedang dilakukan penilaian. Dengan begitu, pimpinan dapat menilai secara langsung bagaimana karyawannya melaksanakan tugas terutama ketika menghadapi pelanggan. 
3. Survei kepuasan pelanggan

Cara lain yang bisa dilakukan oleh perusahaan travel untuk mengukur kepuasan pelanggannya adalah dengan melakukan survey kepuasan pelanggan. Perusahaan travel dapat melaksanakan survey sendiri atau meminta bantuan lembaga riset yang memiliki keahlian dan kemampuan di bidang penelitian. Melalui survey ini, perusahaan akan memperoleh tanggapan langsung dari pelanggan dan hasil yang diperoleh dapat digunakan oleh perusahaan sebagai sumber masukan guna perbaikan.

\section{Simpulan}

Persaingan bisnis pada era pemasaran modern ini semakin ketat, termasuk persaingan pada perusahaan penyelenggara (travel) haji dan umroh di Banjarmasin. Salah satu cara yang harus dilakukan oleh perusahaan untuk dapat menghadapi dan memenangkan persaingan adalah dengan memberikan kepuasan kepada pelanggannya. Diharapkan dengan kepuasan ini akan memberikan keuntungan jangka panjang bagi perusahaan.

Nilai yang diberikan oleh pelanggan sangat kuat didasari oleh faktor kualitas jasa. Oleh karena itu, kualitas jasa merupakan sebuah kata yang bagi penyedia jasa merupakan sesuatu yang harus dikerjakan dengan baik dalam rangka meraih keunggulan yang berkesinambungan. Dengan menitikberatkan perhatian pada dimensi kualitas jasa, diharapkan kepuasan pelanggan dapat diperoleh oleh perusahaan.

Travel haji dan umroh hendaknya mengukur kepuasan pelanggan secara terus menerus dan berkelanjutan karena kepuasan pelanggan ini bersifat dinamis. Kepuasan pelanggan memberikan sejumlah arti penting bagi kelangsungan hidup perusahaan. Oleh karena itu, penting kiranya untuk mengukur kepuasan pelanggan bagi travel haji dan umroh di Banjarmasin dengan menggunakan strategi yang sesuai karena hasilnya diharapkan dapat memberikan gambaran tentang bagaimana tingkat kepuasan pelanggan dan sumber masukan guna perbaikan pengelolaan manajemen perusahaan.

\section{Daftar Pustaka}

Dewi, Ike Janita. 2009. Creating \& Sustaining Brand Equity (Aspek Manajerial dan Akademis dari branding). Penerbit Amara Books. Yogyakarta.

Dewi, Nurmala. 2013. Pengaruh Direct Mail dan Telemarketing Terhadap Keputusan Pembelian Paket Umrah Raka Tours and Travel (Survei Pada Pengguna Paket Umrah Raka Tours and Travel. Universitas Pendidikan Indonesia.

Hasan, Ali. 2013. Marketing dan Kasus-kasus Pilihan. CAPS.

Yogyakarta.

Kotler, Philip. 2002. Manajemen Pemasaran. Edisi Milenium. Jilid 2. PT. Ikrar Mandiriabadi. Jakarta.

Kotler, Philip. 2005. Manajemen Pemasaran (Terjemah). Jilid 1 dan 2. PT. Indeks. Jakarta.

Kotler, Philip and Gary Armstrong. 2012. Prinsip-prinsip Pemasaran. Edisi 13. Jilid 1. Erlangga. Jakarta.

Kotler, Philip dan Keller. 2007. Manajemen Pemasaran. Jilid 2. Edisi ke Dua Belas. PT. Indeks. Jakarta.

Lamb, Hair McDaniel. 2001. Pemasaran (Terjemah). Jilid 1 dan 2. Salemba Empat. Jakarta. 
Rangkuti, Freddy. 2004. The Power Of Brands (Teknik Mengelola Brand Equity dan Strategi Pengembangan Merek). PT.Gramedia Pustaka Utama. Jakarta.

Tjiptono, Fandy. 2002. Strategi Pemasaran. Andi. Yogyakarta. https://id.wikipedia.org/wiki/Pemasaran.

www.kalsel.kemenag.go.id. 